\title{
Castle studies and the 'landscape' agenda
}

\author{
O. H. Creighton and R. A. Higham
}

\begin{abstract}
The growth in interest in the wider settlement settings and landscape contexts of medieval castles is reviewed. While overtly militaristic approaches to castle study sometimes ensured that sites were frequently examined in isolation from their surroundings, some early scholars were aware of the importance of viewing castles in their wider contexts. From the 1970 s onwards, excavation, survey and settlement studies have all made a decisive contribution to our enhanced understanding of the 'landscape' dimension of medieval fortification. Changing approaches to the study of Norman castles, in particular, are explored, and recommendations for future study are identified.
\end{abstract}

KEYWORDS

Castles, settlements, medieval, historiography

\section{INTRODUCTION}

This paper reviews the growth in common ground between castle studies and landscape studies: two branches of scholarship sharing an interdisciplinary approach yet distinguished by very different traditions. Despite the attention devoted by early castellologists (or castle scholars) to the siting and distribution of castles, it is only comparatively recently that archaeological survey and fieldwork has begun to investigate the wider settings of castles and illuminate something of their impact on the development of the historic landscape. Attention has been drawn, for instance, to the status of castles as symbols of power in urban townscapes as well as to sites of rural lordship frequently associated with deer parks, ecclesiastical sites, garden features and medieval settlements, while excavation reports have broadened their horizons to set castles within their surrounding human as well as physical landscapes. This paper draws selectively on the published results of related scholarship; it does not attempt a full historiographical treatment, but endeavours to evaluate some previous research and to highlight avenues for future work that will progress beyond the formulaic scene-setting paragraph so often used to introduce the publication of a given castle (or the often notional attention devoted to a castle's surroundings in a guide book). It also seeks to highlight the contribution that studies of castles can make to landscape history more generally.

\section{CASTLES AND THEIR CONTEXTS}

It is a truism that medieval castles 'dominated their landscapes. But this apparently simple statement obscures, and indeed misrepresents, the many and varied ways in which castles were both embedded in the medieval landscape and contributed to its evolution and character. So closely were the functions of castles related to the organisation of their contemporary landscapes that it initially seems somewhat surprising that many early writers overlooked or ignored their wider settings. The reasons for this are deeply rooted in the historiography of the subject, and in particular the 'building-centric' approach focused on discrete monuments (whether masonry structures or earthworks) that was ingrained in castle studies from the start. Castles were, however, rooted within medieval landscapes at a number of levels: as manorial centres and often the hubs of estate networks; as centres of consumption drawing on the resources of town and country; as constituents of the total settlement pattern and sometimes catalysts for rural and urban settlement change; and also, less tangibly, in a cognitive sense as visual emblems of status and lordship. We can also recognise that, on the one hand, castles were inserted into, and were in many cases clearly related to the organisation of, earlier landscapes and, on the other hand, often had long-term legacies, either as relict features or as reinvented high-status elements that continued to influence landscape development.

The word 'landscape' can sometimes be taken as meaning an arbitrarily defined stretch of territory; alternatively, it can mean an area whose natural and anthropogenic components articulate together, so its character and texture is more than the sum of its parts. It is actually quite difficult to see what notion of 'landscape' is best applied to defended sites: often these were 'in' landscapes rather than 'of' them. Thus, a 
contrived ornamental 'landscape' around a medieval seigneurial centre was obviously something whose detailed character the manipulator was aware of; yet a 'landscape' defended by a network of sixteenth-century or later coastal defences was little more than synonymous with vulnerable points on the frontier of the 'state' in question.

Perhaps most crucial of all, however, we should be critically aware of distinguishing between the notion of the 'landscape' of a castle as perceived by its creators and inhabitants, and that created by the modern observer whose attitude is influenced not only by hindsight but also by various methods of enquiry. There is, of course, no single most appropriate scale of analysis at which to conceptualise the landscape context of any given castle. Rather, different types of setting were nested one inside the other: the context of a site within a 'national' network or pattern of fortifications; the seigneurial site within its lordship, manor and parish (which may not be the same thing); its setting in relation to secular settlements and networks of ecclesiastical patronage; the physical topographical character of its immediate environs; its juxtaposition with nearby features of status such as parks, fishponds, gardens, dovecotes and mills; and, perhaps, the 'intra-site' landscape of inner and outer enclosures or wards. And if there are many ways of conceptualising the landscape settings of castles, there are many ways of representing them visually too. Architectural photographs of buildings and their backgrounds, scaled hachure or contoured plans of earthworks, maps of administrative and tenurial frameworks, aerial views and topographical and distribution maps all provide different perspectives on a castle's context. While each form of representation has a different contribution to make, we must note that none in isolation actually tells us very much; all are artificial constructions that, alone, offer little insight into how castles and their landscapes were experienced by contemporary individuals or groups. For instance, while it might be common practice in excavation reports, field surveys and guidebooks to depict castles as the gravitational centres of their localities, most castles represented nodes of power and influence in more complex webs of lordship: the estates over which they exercised authority were frequently non-contiguous and included farflung interests and properties, and many actually lay at the boundaries of different resources, for instance between upland and lowland zones, or on the fringes of villages, towns, deer parks and forests.

In addition, just as we are accustomed to thinking of 'polite architecture and landscapes' from the seventeenth century onwards, the medieval castle had this quality too in its capacity as a 'country house' (Saunders 1993). It is really in this sense, rather than in terms of supposed defensive qualities, that the castle really has a 'landscape dimension', in the deliberate manipulation of its surroundings for aesthetic and functional effect. While we might stress the importance of understanding the setting of any given castle from a variety of angles and perspectives we should certainly not overlook that there is much to be gained by also thinking of the 'landscape' of any particular site in the strict sense of the word, meaning a view from a particular defined point — for instance, a park as viewed from the bench-seat inside a castle window. In this sense there is a connection between the 'landscape' of a castle as a tract of territory and the notion of the artist's 'landscape' as something artificial and contrived for aesthetic effect - the original meaning of the word, which has unfortunately often become lost in modern archaeological discussion.

But the historiography of castle studies shows a number of other trends that have frequently ensured the artificial severance of castles from their settings. Aside from the powerful militaristic bias within the subject discussed below, the dominant mode of architectural enquiry has tended to break sites down, through analysis of defensive and domestic structures, into component parts, while the traditional approach to synthesis has tidied Britain's castles into a sequence of ever-onwards, ever-upwards increasing sophistication of design. Frequently, any attention given to a castle's setting has usually, and perhaps inevitably, taken the form of descriptive background material providing context for a more focused discussion of the core features of the monument in the foreground. This long-term trend, whereby the agenda of architectural study has consistently retarded ambition towards a more holistic understanding of castles, both in toto and within the context of their immediate surroundings, is one manifestation of what has been termed the 'Orford syndrome' (Welfare et al. 1999, p. 53). The famous polygonal donjon at Orford (Suffolk), built to the orders of Henry II, has been slotted into innumerable popular and academic texts on account of its architecturally 'transitional' form - its photographic portrait a familiar feature of Britain's castle heritage. Yet the immediate landscape context of this architectural fragment - representing only the tip of the iceberg of a huge and complex suite of related earthworks and other masonry features known from documentary, field and pictorial evidence - remains frequently overlooked, as does its status within the settlement pattern. As well as being a symbol in a political power-play between the king and the Bigod family, the castle was only one manifestation of a more ambitious venture, with royal interest invigorating the local economy and settlement of Orford which, through a scheme of marshland 
drainage, was upgraded into a thriving port generating a greater volume of trade than Ipswich by the thirteenth century (Poole 1955, p. 96; Heslop 1991).

\section{DEVELOPMENT OF THE 'LANDSCAPE APPROACH' IN CASTLE STUDIES}

While the 'landscape approach' to castle studies became increasingly fashionable from the $1980 \mathrm{~s}$ onwards, acknowledgement of the broader contexts of castles was not totally absent in early scholarship, and care must be taken not to oversimplify how the agenda of castle studies has evolved. In particular, it is tempting yet erroneous to caricature the militaristic tendency within the subject, which, while enduring, was not all pervading. It is all too easy, for instance, to paint a crude picture of a 'social/symbolic' interpretation of castles emerging to challenge and supplant the perceived militaristic orthodoxy of traditional scholarship towards the end of the twentieth century (compare Stocker, 1992 and Thompson, 1994; see also Liddiard 2003 for discussion). Ella Armitage's seminal The Early Norman Castles of the British Isles (1912), for instance, looked far beyond the physical characteristics and chronological development of early castles. Through extensive map-work, Armitage systematically examined the distribution and setting of mottes in support of her thesis that they were Norman impositions as opposed to Saxon burhs, noting in particular their intrusive positioning within townscapes (see also Armitage 1904; Counihan 1990). Armitage's interest in the settings of early castles was also apparent in her often overlooked contributions to the Victoria County Histories; the volume for Yorkshire, for instance, noting the positioning of many mottes near to parish churches, and their association with Domesday estates as evidence that the origin of these castles was manorial rather than military' (Armitage \& Montgomerie 1912, pp. 19-20). Another early contribution of significance was Allcroft's pioneering Eartbwork of England (1908), which in a discussion of castles as field monuments recognised their frequent superimposition on earlier sites of significance and the re-use of their earthworks after abandonment (ibid. pp. 400-52) (Fig. 1). Yet the following history of castle scholarship demonstrates that this early recognition of the wider contexts of castles was subsequently rather lost sight of and overshadowed by studies of the castle as an essentially military artefact (see for instance Hamilton Thompson 1912; Braun 1936; Brown 1954) only for the 'landscape approach' to be re-discovered much later in the century.
The two seminal works that, together, represent the foundation stones of modern landscape history made only tangential reference to the impact of castles. In The Making of the English Landscape, W. G. Hoskins (1955, p. 91) briefly acknowledged the close linkage between castle-building and town foundation, citing prominent examples such as Devizes (Wiltshire), Launceston (Cornwall) and Ludlow (Shropshire) but, even in a predominantly rural study, largely overlooked the contribution of castles to the countryside. O. G. S. Crawford (1953, pp. 18897) revealed a little more of the potential for studying the landscapes of castles in Archaeology in the Field, which devoted a chapter to how analysis of historic maps could help trace the plans of medieval parks attached to the earthworks of Norman castles, as at Merdon Castle (Hampshire) and Hamstead Marshall (Berkshire). Yet a pattern was established: studies of castles traditionally lay beyond the perceived boundaries of landscape history (and, of course, vice versa).

It is now more than twenty years since a paper was written by David Austin (1984) on the subject of 'The castle and the landscape', representing something of a call to arms imploring archaeologists and historians to look beyond the defensive perimeters of medieval fortified sites and re-integrate them within their surroundings. We might also note how, in the late 1980s, the founding statement of the Castle Studies Group included a desire 'to promote the study of castles as resources for a more widelybased appreciation of medieval society, emphasising their social and political history, their defensive and domestic evolution, their rôle in settlement development and their value as a source for the reconstruction of landscapes and economic environments' (Castle Studies Group 1987 , p. 2). While these developments identified an academic and intellectual rationale for examining castles in their broader contexts, this is not to say either that previous scholarship neglected utterly the landscapes around castles, or that subsequent work has exploited the intrinsic worth of this type of approach to its full potential. From this time onwards, however, castle studies have progressively recognised, if not quite embraced, the interdisciplinary methodologies and insights of landscape study. The outcome has been an increasing realisation that the physical contexts of castles can be interrogated and unravelled in a way that not only informs about sites themselves, but can feed into more general debates within the fields of landscape study and settlement history.

A brief examination of how interpretations of Norman castle siting and location have evolved during this period provides, in microcosm, an account of the changing agenda of castle studies. 


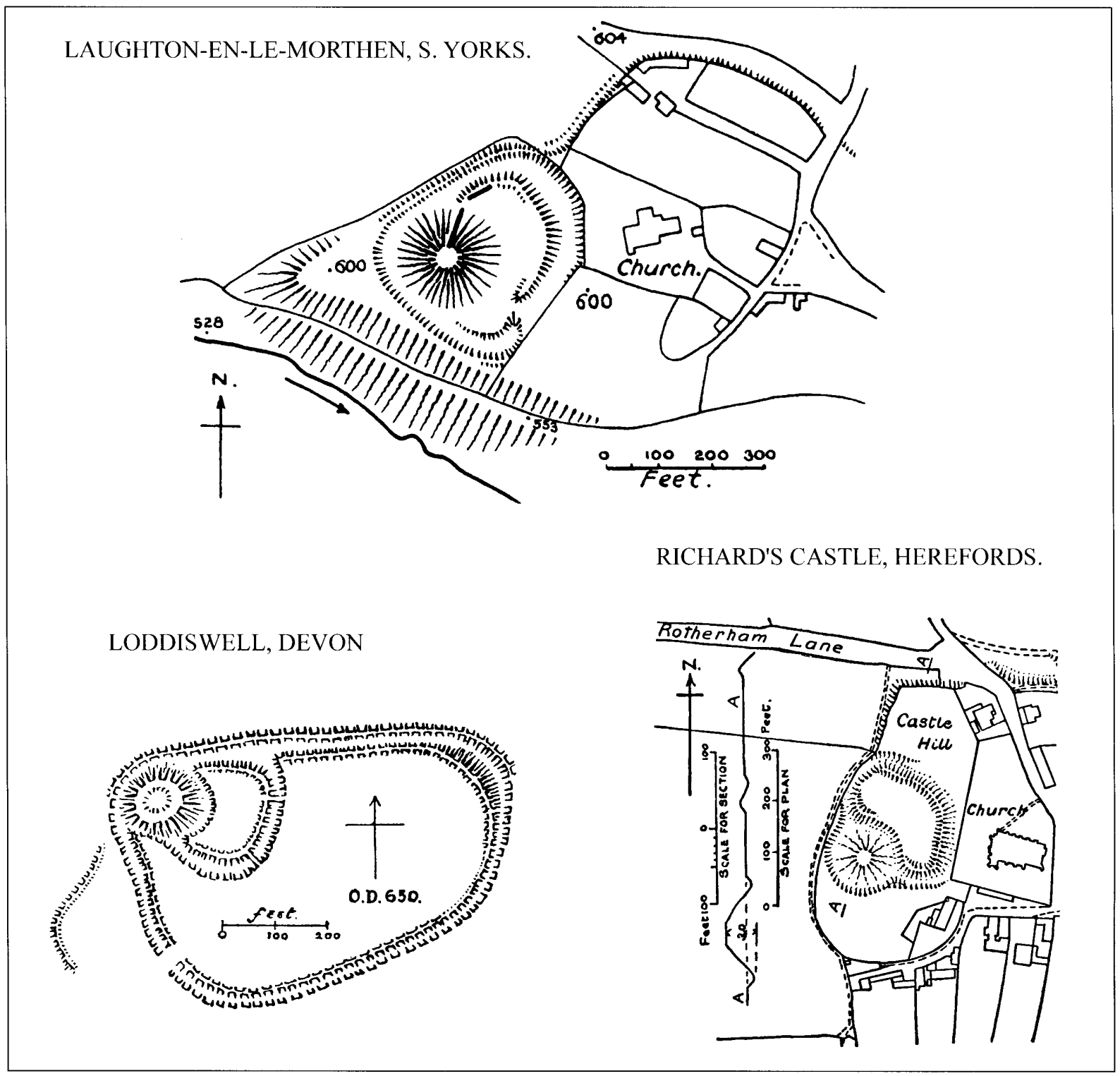

Fig. 1. Earthwork remains of three early castle sites, as depicted in the early years of the twentieth century. Source: Armitage 1912 (Richard's Castle); Armitage \& Montgomerie 1912 (Laughton-en-le-Morthen); Allcroft 1908 (Loddiswell). Works such as these represent the foundations of the field archaeology of castles, and often paid attention to the immediate settings of field monuments.

Much of the language traditionally used to describe the landscape settings of Norman castles owed more to the post-medieval fortresswarfare associated with military engineers such as Vauban and Coehorn, than it did to the reality of the medieval world. It became deeply ingrained in archaeological thinking, for instance that military factors conditioned the siting of Norman castles, so they 'commanded', 'overlooked' or 'controlled' topographical features such as fords, ferry-crossings, passes and roads and 'dominated' human populations. A strong and early tendency towards the militaristic explanation of castle siting leaps out from the writings of soldierly antiquarians and early military historians, overlooking the multifarious functions of castles to see them primarily as features of military heritage (see, for instance, Grose 1801, pp. 1-8; Oman 1898, pp.
21-2; Harvey 1911, p. 3). Hilaire Belloc (1912, pp. 17, 21, 33), for instance, explained patterns of castle-siting with explicit reference to features of England's 'strategic geography' such as the 'Manchester Gap', considering many castles to have been sited specifically to check lines of advance. Far more recently, it has been conjectured that a string of castles along the Thames formed a Norman forward line, while another line between the Thames and the coast constituted a stop-line in the manner of Second World War fortifications (Hill \& Wileman 2002, pp. 88-9).

The greatest exponent of the 'grand strategy' explanation of castle-building and the relationship between castle location and a supposed 'military landscape' has been the historian John Beeler (1956; 1966). He saw the Norman castles of England as the outcome of a 
newly imposed authority's master-plan to conquer and pin down an indigenous society using a strategic network of fortifications, his arguments loaned authority by modern military analogies ranging from the campaigns of the Duke of Marlborough to actions of the American Civil War. The centrepiece of Beeler's thesis was a map depicting the distribution of castles of suspected eleventh-century date relative to a reconstruction of the contemporary road network and key population centres (Fig. 2). For instance, London and Coventry - both identified as nodal points on the communications grid - were seen to have been protected by screens of fortifications covering road junctions and lateral routes (1956, pp. 594-

\section{7; 1966, pp. 53-5).}

The most recent contribution to the debate over royal power and the explosion of postConquest castle-building is by Eales (1990), emphasising (from a data set substantially enlarged since the time of Beeler's writing) that the unique socio-political nature of the Conquest of England actually ensured a lesser degree of centralised control over private fortification than in Normandy. In short, private fortification spread unusually far down the social hierarchy in the period c. 1066-1200, so that a large proportion of the sites built (and many subsequently abandoned) during this time were the manorial centres of petty lords (ibid., pp. 54 63). From a more general point of view, the 'grand strategy' view of Norman castle-building suffers some of the generic weaknesses associated with basing arguments on distribution maps of field monuments: in particular the issue of assuming sites to be contemporaneous when in fact the pattern of castle-building was cumulative. Updated distribution maps of Norman castles highlight the unseverable connection between the construction of private castle sites and the establishment of lordships, in addition to a lack of a defensive logic in their overall siting, as revealed for instance in the basic lack of truly coastal castles (as opposed to those with links to communications networks through estuarine positions) and the fact that densities along borders are clearly not the outcome of a co-ordinated strategy (McNeill \& Pringle 1997; see also Creighton 2003, pp. 4654).

The tradition of cataloguing the field monuments of early castles, effectively started with the Victoria County Histories and given further impetus by the RCHME, reached a climax in the form of the magisterial Castellarium

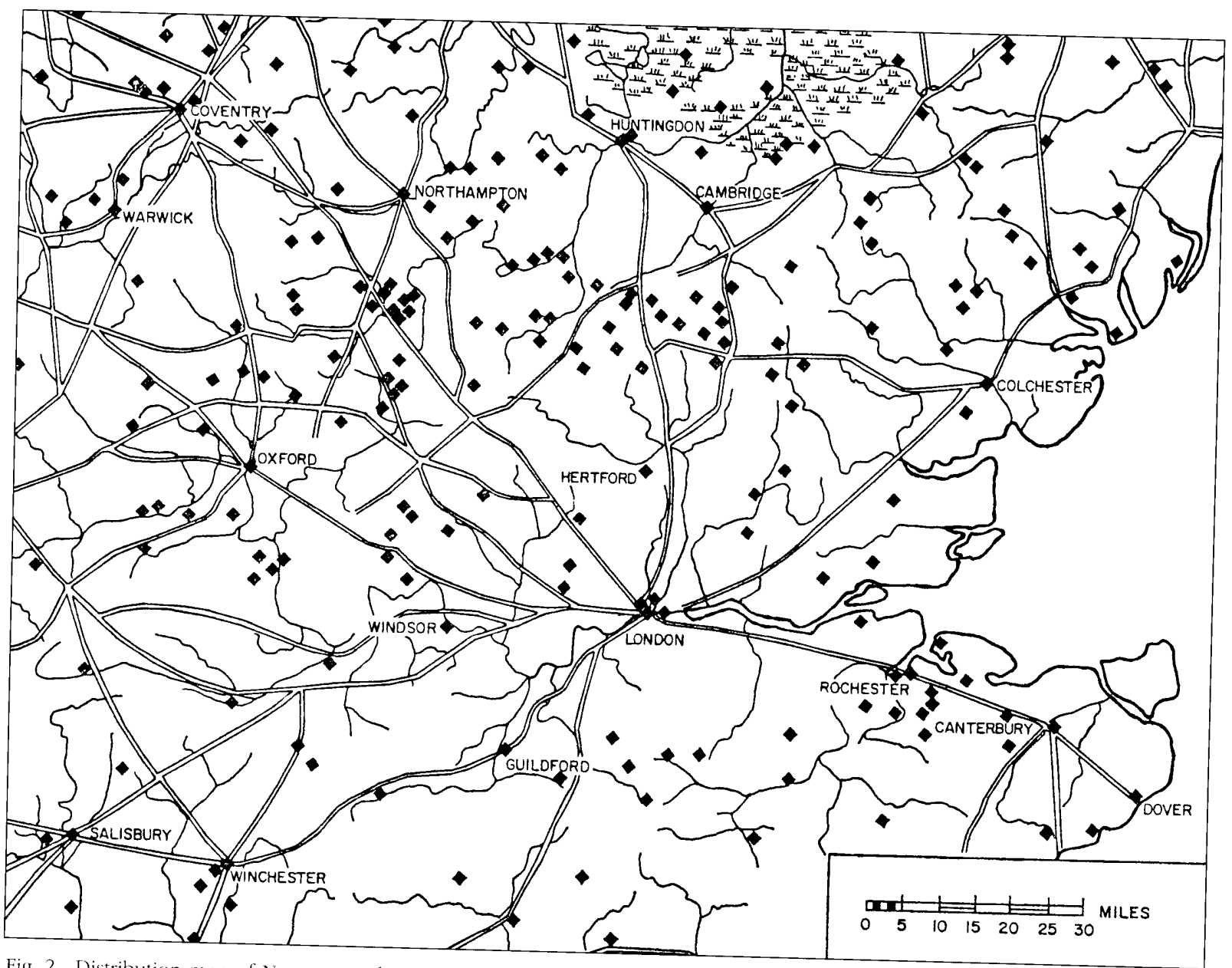

Fig. 2. Distribution map of Norman castles in an area of south-east England. Source: after Beeler 1966. 
Anglicanum (King, 1983). Still forming an essential starting point for castle-related research within any given area, this volume makes clear the large number of 'minor' manorial castles that dotted the countryside, many of them undocumented (in counties such as Herefordshire and Shropshire this was actually true of the majority of all castles). Of a total of 1,125 castles in English counties listed by King (ibid.), approximately 82 per cent (922) are found in rural situations, and of the remainder, the vast proportion (13 per cent or 146 sites) were associated with planted towns, and merely 5 per cent ( 57 sites) were true 'urban' castles imposed into extant townscapes (Creighton forthcoming). Such statistics give another type of context to analyses of individual sites, emphasising quite simply the breadth of castlebuilding society and the castle's flexibility as an institution, readily adaptable to a vast array of socio-economic and tenurial circumstances in different landscapes. The armoury of the landscape historian can frequently be deployed to provide tenurial contexts for undocumented mottes and ringworks, whose 'historical' context can be deduced by identifying the history of associated land tenure and perhaps ecclesiastical and borough foundations (see for instance Higham 1982; Creighton 2000). A particularly illustrative example of this approach relates to the motte and bailey castle at Abinger (Surrey), well known in medieval archaeology as one of the very first castles where excavation revealed the remains of a timber structure. While the wider context of this site remained totally obscure in the original report (Hope Taylor 1950), where it is presented as a martial watchtower rather than a manorial feature, detailed reconstruction of the locality's tenurial geography at the end of the eleventh century has shown it to have been at the centre of a small estate sub-infeudated to Robert of Abinger, the motte raised in a characteristic position adjacent to the lord's church (Blair 1981).

Ultimately, explaining patterns of private Norman castle-building across the landscape in abstraction from their related lordships is almost meaningless, as is discussion of their siting without reference to the contexts of these sites within the contemporary settlement pattern, given, for instance, the common status of so many mottes and ringworks as seigneurial cores within communities. The renowned historian of the Norman period, John Le Patourel (1976, p. 28), argued that the Norman Conquest comprised two phases: military action succeeded by colonisation; what broad-based study makes increasingly clear is that while castles are commonly thought to be products of the former (and, incleed, sometimes were), their cumulative distribution is more intimately related to the latter.

\section{FIELDWORK, EXCAVATION AND THE LAND- SCAPE AGENDA}

Two research projects, in particular, can be singled out as having broken the mould in terms of seeking to re-integrate medieval castles with their contemporary wider settings. The long-term research project focused on the earth and timber castle of Hen Domen (Powys) has witnessed the armoury of landscape fieldwork not only supplementing the results of detailed excavation, but feeding actively into a research design and casting genuinely new light on a site. Present from the very early stages of the project in the 1960 s, the importance of this work is reflected in a dedicated chapter of the final report not, as so often, taking the form of an obligatory scenesetting exercise, but lying at the heart of the resulting monograph (Higham \& Barker 2000, pp. 141-57) (Fig. 3). This chapter illuminates the landscape that was superseded by the building of New Montgomery castle in the thirteenth century and explores a wide variety of settlement, social and economic themes; even so, many questions remain. An important lesson can be found in the fact that, even in what amounts to probably the most detailed study of an earth and timber castle in Europe, some aspects of the site's environs remain totally obscure. In particular, the crucial question of whether the castle was throughout its life an isolated feature in a dispersed settlement landscape dispersed or was eventually associated with a dependent settlement or borough remains unanswered and perhaps unanswerable. While there are suggestions in the documentary record that a borough was being encouraged by the de Bouler lords of the castle in the late twelfth century, and while this may lie under the hamlet east of the castle, its physical character remains uncertain (Barker \& Higham 1982, p. 12; Higham \& Barker 2000, pp. 11-12, 149). An equally important contribution to knowledge is reflected in the excavation report relating to the royal fortress of Portchester Castle (Hampshire). The section devoted to the broader setting of the site in its later medieval phases (Munby 1985) represented something of a masterclass in the synthesis of documentary and cartographic material relating not only to the local environs of the castle, but to its broader context within the region, including access to forests and other resources. Among other things, this highlighted an important point: there is no simple correlation between the status of a castle and either the majesty of its setting or the degree of its impact on the local environment. While Portchester Castle was an occasional royal residence, only one-third of the manor belonged to the Crown and sustained the castle with rentals and other resources; the remainder had been granted to Titchfield Abbey since the 1230 s, and in the open fields surrounding the 


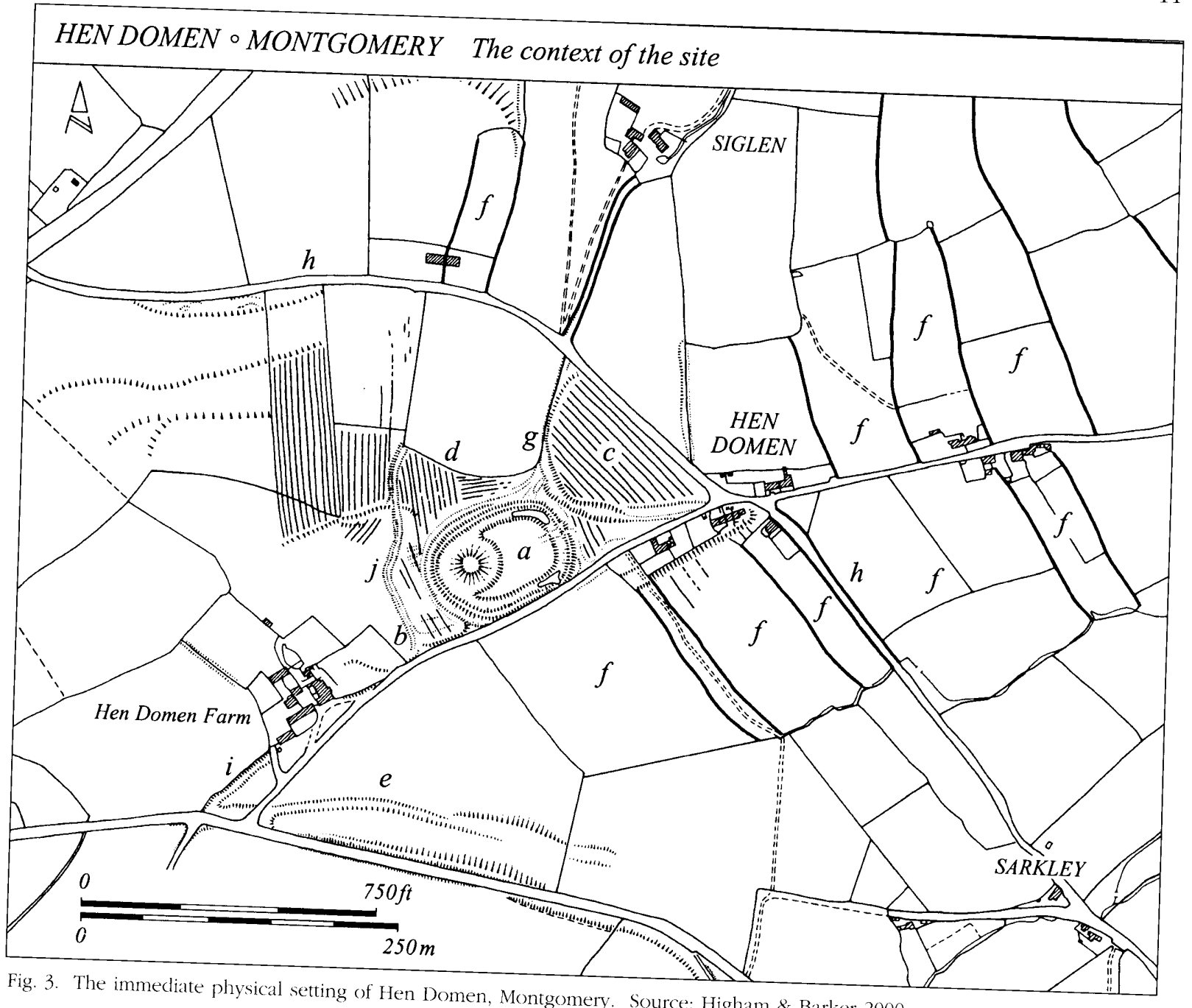

Fig. 3. The immediate physical setting of Hen Domen, Montgomery, Source: Higham \& Barker 2000.

castle the holdings of the Abbot and the king were intermixed. The appending settlement, meanwhile, while developing pretensions as market village, never achieved borough status, being economically overshadowed by the growth of Portsmouth and constrained by the dual lordship of the manor, despite the castle's élite status. Whereas the excavation and conservation of castles in state ownership had traditionally been wholly site orientated, from the 1970s onwards such projects were also taking on a landscape dimension, as at Okehampton (Higham 1977) and Launceston (Saunders forthcoming), two projects that complemented one another - one a study of a castle-borough nucleation and the other examining a castle in a rural dispersed settlement pattern with a new borough well distant - as well as the work at Portchester.

Against this background, of projects incorporating landscape analysis as an integrated aspect of project design, we can also note another trend: in which earlier interpretations of discrete sites have been radically shaken up and overturned by field survey and related research relating to their immediate physical settings. A prime example of this is the archaeological report on the royal castle and hunting lodge of Ludgershall (Wiltshire) (Pl. I). Here, the results of a $1960 \mathrm{~s} / 70 \mathrm{~s}$ castle excavation were set in a radically new light by a programme of $1990 \mathrm{~s}$ survey and archaeology, highlighting a hitherto unrecognised aesthetic aspect to the site's earthworks and wider setting. In particular the broad and level outer bank of the northern enclosure previously identified as the outermost of two concentric ramparts, seems actually to have functioned as a garden-walk accessed from interior structures (Everson et al. 2000). A defining feature of the entire ensemble was the existence of dual deer parks: a pleasure park unit enveloped the site on three sides, while a detached deer park of more functional and economic purpose lay to the south, with the two bracketing the town and profoundly stunting its growth. Stafford Castle is another site where understanding has been altered considerably by detailed and non-intrusive interrogation of surface remains, complementing and in some senses challenging interpretations from excavation. The present field monument comprises a nine-hectare island of particularly 


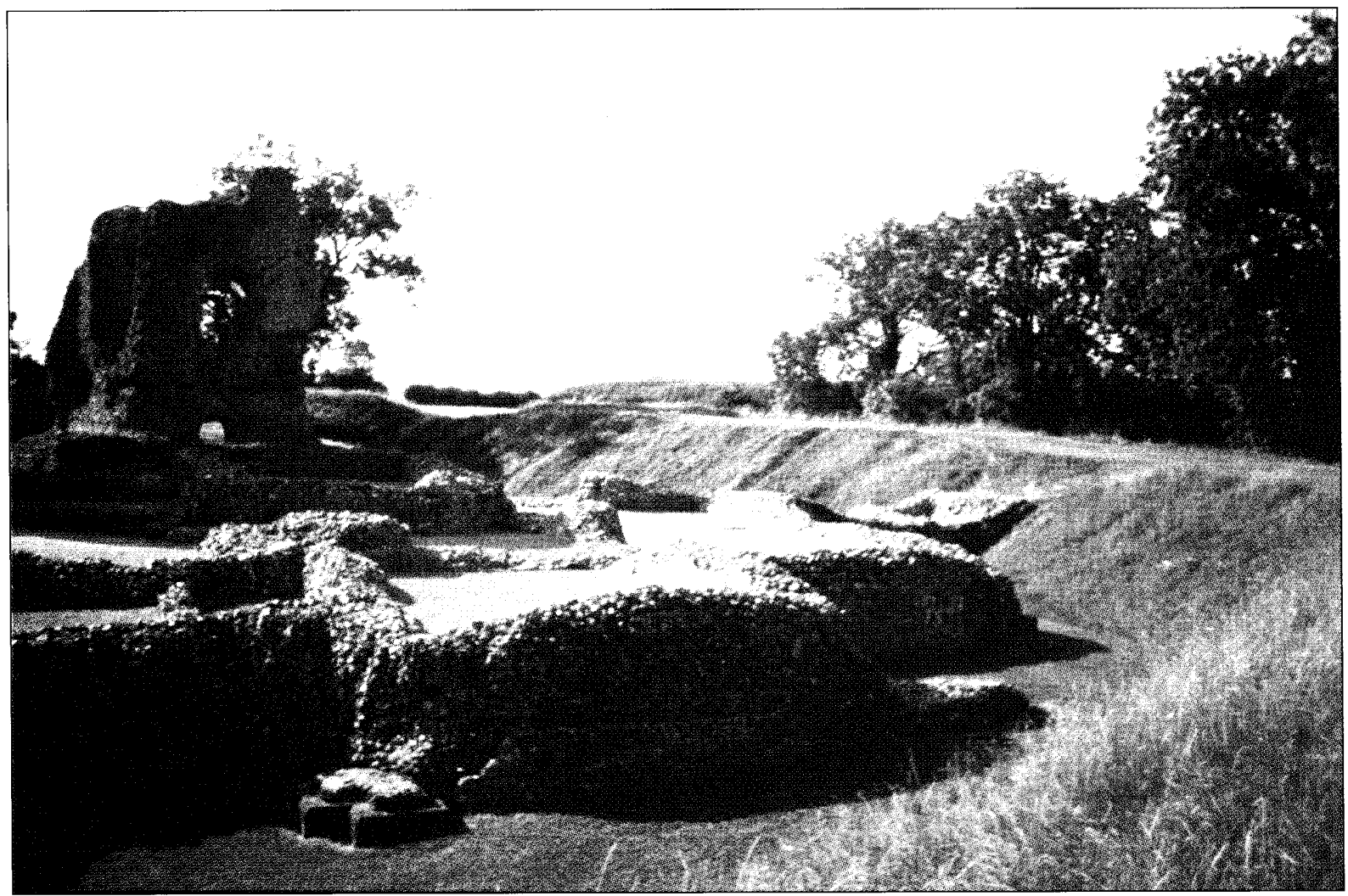

Plate I. Ludgershall Castle, Wiltshire: (left) masonry remains of domestic buildings: (right) earthwork remains of broad flat-topped bank. The perimeter earthworks at this royal castle and hunting lodge, traditionally interpreted as defensive features. are now thought to have included a terrace from which views of the surrounding park coukl be enjoyed. thus providing visual linkiage between the royal quarters and their landscape setting. The site was founded shortly after the Vorman Concluest and went through many periods of rebuldeing: the use of the earthwork as an ornamental terrace appears to have been a derelopment of ce 120 o. (Photo. the authors)

complicated multi-phase earthworks centred on the stub of a folly built on the foundations of a fourteenth-century donjon standing on an even earlier motte. An aerial view of the site demonstrates clearly the richness of this surrounding palimpsest in contrast to the paucity of architectural evidence, serving as something of a visual metaphor for the need to put the masonry remains of castles in their places. Notably, while several published plans and reconstructions of the site have depicted a fortified community representing the lost settlement of Monetvile within an outer enclosure appended to the castle (Higham \& Barker 1992, pp. 289-93; Hill \& Klemperer 1995), later detailed earthwork survey has brought this interpretation into question. These remains seem, rather, to represent garden features, forming part of an ornamental setting that included garden terraces beneath the donjon and also incorporated a deer park forming a backdrop which visually enhanced the site (Jecock \& Corbett 2001, pp. 99-100).

This evidence means that Stafford Castle can be added to the rapidly growing group of later medieval castles known to have been embedded within contrived ornamental surroundings. Of these, the most widely recognised is Bodiam
(East Sussex) - which has played a decisive rôle in stimulating debate over the existence and character of large-scale designed landscapes in the medieval period (Taylor 1998, 2000; see also Johnson 2002), and is worthy of a historiography in its own right. What differentiates Stafford from most others with recognised ornamental settings, however, is that this little landscape, like Ludgershall (but in contrast to Bodiam), did not incorporate water features. A priority for the future is certainly to iclentify other sites in designed settings that did not incorporate water features. Yet the rise in interest in later medieval designed landscapes should not deflect attention away from the likelihood that an aesthetic and symbolic dimension to castle siting was not entirely absent in the eleventh and twelfth centuries. Several recent studies have highlighted pressing evidence for this. In particular, scrutiny of the settings of major East Anglian Norman castles including Castle Acre and Castle Rising has shown that approach routes were contrived to draw attention to high-status elements within designed environs featuring deer parks, planned settlements and ecclesiastical sites, the visual appearance of the castles themselves being highlighted by carefully selected positions without primarily military qualities and 
sometimes on 'false crests' (Liddiard 2000a, $2000 \mathrm{~b})$. Research on Cornish deer parks has shown essentially similar forces at work in the selection of castle sites and the remodelling of their environs (Herring 2003). The plan of the castle park at Launceston, for instance, carefully manipulated the views of visitors to the town as a display of the status of the earls and Dukes of Cornwall, while at Restormel the park visually enhanced the secluded qualities of the site, and a level terrace around the perimeter of the shell keep may well have been a viewing device as noted at Ludgershall. Such studies are a useful complement to another current and profitable mode of enquiry applied to castles of the eleventh to thirteenth centuries: the analysis of access patterns and the use of social space in the domestic planning (see, for instance, Dixon 1998). Both approaches have highlighted that, at completely different scales, sophisticated control and manipulation of access could be an important mechanism for the expression of lordship, and this is attested not only by buildings but entire compositions of sites and their surrounds.

Most such studies relate, however, to the settings of sites containing at least some monumental masonry structures. Higham and Barker (1992) have highlighted that timber-built sites were not necessarily the poor relation to masonry castles, and a further question remains concerning whether the settings of earth and timber fortifications could similarly have iconic qualities. While castle studies have seen a good deal of recent revisionism concerning the functions and symbolism of castles in the later medieval centuries, the Anglo-Norman period perhaps remains more disputed ground in this regard, being frequently caricatured as the "military centuries' (see Lidcliard 2003). At Hen Domen, for instance, it has been suggested that the intervisibility of the motte with a large tract of the surrounding lordship was an important part of its social role in the twelfth century, although this was not perhaps the original intention of its eleventh-century founder (Higham \& Barker 2000, p. 178). Here, as perhaps elsewhere, we may also note the contrast between the site's impressive external appearance and the reality of its cramped interior: To return to the aforementioned report on Stafford Castle, particularly telling is the observation that symbolism was an ever-present feature of this site and not simply introduced with the building of Ralph Stafford's unusual keep of c. 1348: the type of late medieval structure sometimes termed a cult castle" (Darlington 2001, p. 149). The eleventh-century timber castle surmounting the motte and bailey that formed a prominent feature on the skyline in full view of the county town, yet by no means in the strongest defensive position in the locality, was a potent and iconic symbol of ambition, just as the castle's early nineteenth-century reconstruction by the Jerningham family had symbolic significance as an appropriation of the medieval past, as was so often the case where the fabric of castles was incorporated into postmedieval parks and gardens. Here, symbolism was a major quality of the site that 'survived' the supposed 'decline' of the castle. This example highlights a fascinating but under-researched subject of the ways in which the symbolic qualities of castles were continuously reinvented down to the nineteenth and twentieth centuries through manipulation of their surroundings.

Quite how radically re-analysis of an early castle's setting can transform our overall understanding of a site is demonstrated by the example of Goltho (Lincolnshire), a prominent site in British medieval archateology on account of important excavations on both the deserted medieval village and the related manor/castle site. The extent to which the interpretation of the site's landscape setting presented in the original excavation report has been challenged and its understanding revolutionised is evident in the suggestion that the excavated entity was not in fact 'Goltho' at all, but medieval Bullington, confusion arising due to an erroneous correlation of tenurial geography with physical features of the medieval landscape (compare Beresford 1975, 1987 with Everson, 1988, 1990). While the original publication strategy artificially severed the seigneurial site from its associated community and appears to have misinterpreted its tenurial context, detailed re-examination of the surrounding medieval landscape, informed by the experience of a wider archateological survey of the region's medieval settlements (Everson et al. 1991), detected detailed evidence for how the lordly presence was manifested at a local level. Lacking any military or strategic context whatsoever, this particular site of lordship, perpetuating use of the same site from the late Saxon period to the early thirteenth century, was twinned with an adjacent chapel/parish church, and in the post-Conquest period its lords were a puissant force in the locality, engaged in the creation and enlargement of a deer park and the promotion of a Gilbertine priory. A compelling case can also be made that the excavated village attained its developed form through planning by the castle lords in the late eleventh century (Everson 1988; 1990; see also Creighton 2003, pp. 20-7).

The case of Goltho demonstrates how closely issues of castle and settlement development may be connected. Settlement historians have, however, traditionally given castles something of a wide berth, certainly in comparison to features of the medieval landscape such as moated sites, which have warranted far closer attention despite the evident inter-linkage between early castles and landscape exploitation (Creighton 
1999). In this sense a lead can be taken from archaeology in Ireland. Here, studies of castles have more frequently been integrated within the framework of later medieval rural archaeology and Norman fortified sites seen as components within evolving settlement patterns (O'Conor 1998, pp. 25-6). One reason for this is the relative youth of these fields of scholarship in Ireland compared to England (medieval study in Ireland being long dominated by the early Christian period). Another is that enclosed sites formed such an important part of the Irish settlement map in the pre-Norman period, that in this part of Europe castles were always 'at home' in settlement study, with the earthworks of timber castles in particular perpetuating a centuries old tradition of ringforts in the Irish landscape.

In the countryside, as more evidently the case on the urban scene, Norman castles could be catalysts for settlement change; the work of the RCHME in Northamptonshire demonstrated, for instance, numerous cases where castles were active components in sequences of settlement evolution, as at Long Buckby, Culworth and Lilbourne, where the local settlement pattern demonstrated progressive drift away from a castle-church nucleus (RCHME 1981, pp. 125-8). Middleton Stoney (Oxfordshire) (Pl. II) and Laxton (Oxfordshire), two villages similarly well known in medieval settlement studies, are among the many other nucleated villages presenting clear evidence for the intervention of castle lords in settlement planning (Rahtz \& Rowley 1984; Cameron 1980; see also Creighton 2003 , pp. 198, 207-10). Some of the clearest evidence of seigneurial intervention in settlement change can be found, however, in cases where castles are juxtaposed with deserted villages, as at More (Shropshire). These cases and others are highly significant in that castles often form broadly datable elements within such sequences. Indeed, it might be noted how many of the casestudies of post-Conquest settlement change discussed in Christopher Taylor's Village and Farmstead (1983) featured settlements bearing the imprint of lordship in the form of a castle, including places such as Burwell and Castle Camps (Cambridgeshire), in addition to the Northamptonshire examples mentioned above. In all these cases, the existence of castles was crucial to unravelling a sequence of settlement development. Nor should we overlook the status of so many castles as elements in dispersed landscapes. Highly notable is that fact that, far from functioning in isolation from the wider settlement distribution, the settings of most castles mirrored regional settlement patterns, this giving rise for instance, to the high proportion of Devonian and Cornish Norman castles existing

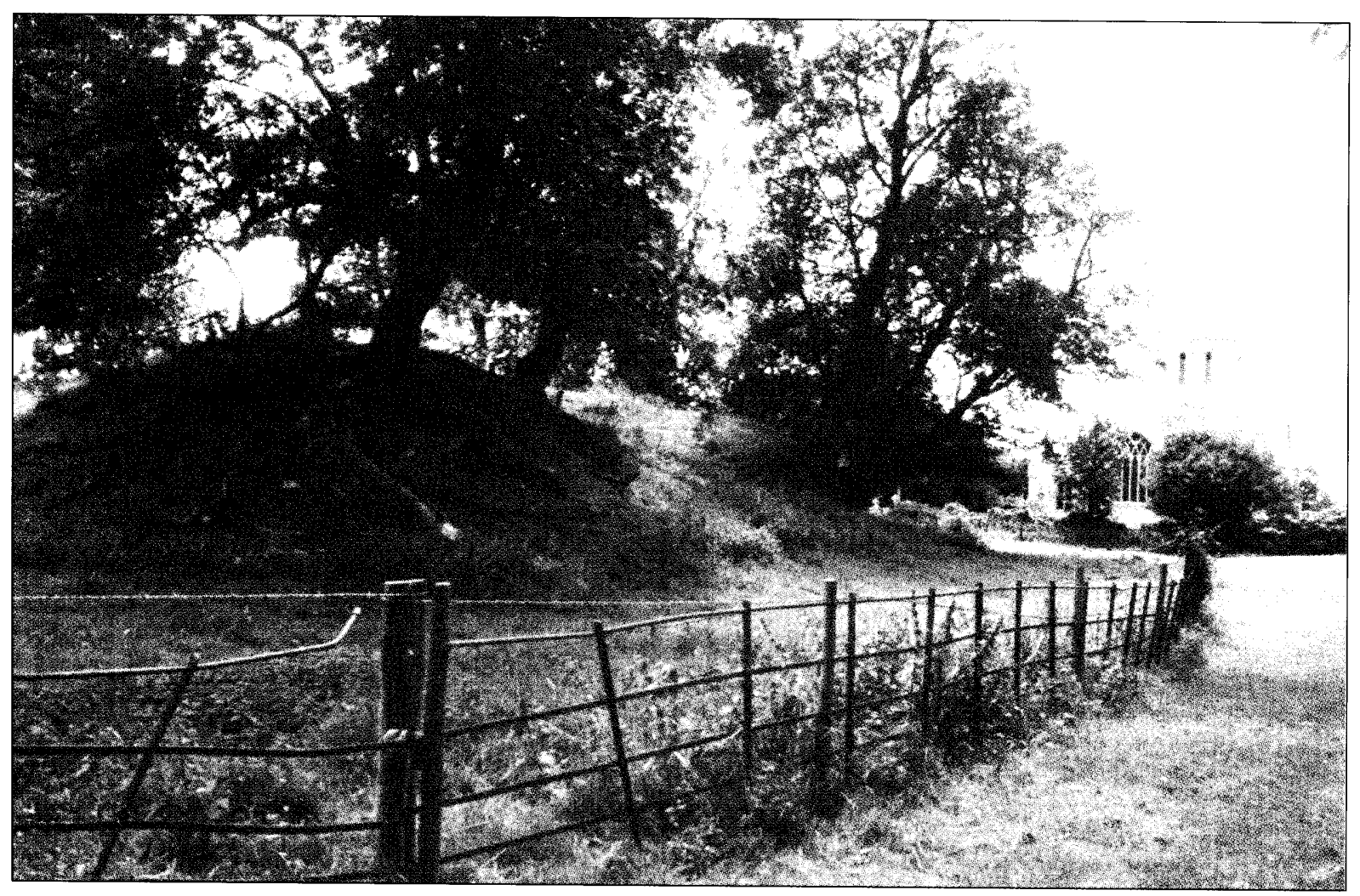

Plate II. Middleton Stoney, Oxfordshire: (left) remains of collapsed tower forming the core of a medieval (astle; (right) parish church of All Saints. This seigneurial castle was a transient feature of the landscape, built in the mid-twelfth century and clemolished in the thirteenth; however, in this short time, the castle lords planned the village, built the church, created a park and re-routed the local road system. (Photo. the authors) 
as discrete features in more fragmented landscapes (Higham 1982, p. 106). Finally, it should not be overlooked that dispersed settlement patterns containing castles could originate from settlement planning too, as was patently the case with the remarkable vale of Montgomery mottes, comprising a densely packed group of twelve small sites reflecting a programme of late eleventh-century land settlement and the economic recovery of a rundown area, as opposed to an interlinked system of military installations (King \& Spurgeon 1965, pp. 84-5)

\section{CONCLUSIONS}

This paper has demonstrated that the study of the wider landscape contexts of castles has not developed evenly over the last century, and has certainly not fully matured. While early scholars, in the period c. 1900-10, were certainly aware of the importance of the landscape dimension to castle studies, the subsequent militaristic emphasis in the subject until the 1970s ensured that this ground was largely lost. Since then, a gradual increase in attention has occurred to the present day. In the twenty-first century, for instance, the Castle Studies Group has hosted a conference on European castles and their hinterlands, while the biennial Château Gaillard Colloque had as the theme of its 2004 conference the subject of castle and settlement.

This upsurge in interest has meant that castle studies have now made up ground on other branches of medieval archaeology, including studies of monasteries, settlements and churches, which, it could be argued, adopted the 'landscape approach' far earlier (see for instance Rowley 1978; Morris 1989; Aston 2000). But while this dimension to castle studies has come on in leaps and bounds in the last two decades, we should be careful not to underestimate the groundwork laid by earlier scholars or to assume that our present approaches and perspectives are adequate. Particularly pertinent here is the fact that so much serious academic study of castles continues to focus on such a small sample of sites, in particular major masonry fortifications. The many hundreds of earth and timber fortifications that dotted the medieval landscape have traditionally been examined in countybased studies (e.g. Creighton 2003), and an urgent need exists to re-interpret these sites in wider settlement and landscape frameworks. The progressive erosion of deeply ingrained preconceptions about the functions and significance of castles also requires such findings to permeate into more popular literature. guidebooks and even the national curriculum. One promising trend in this context, easily overlooked, is the increasing tendency of reconstruction illustrations of castles to put emphasis on the medieval settings of sites as well as on their structural appearance, as shown with representations of Okehampton Castle, for instance (Higham 2001, pp. 140-1) (Pl. III).

What of the agenda for future work? What many of the aforementioned examples, including Stafford and Ludgershall, have in common is that the identification of an ornamental dimension to the settings of these castles hinged on the reevaluation of known earthworks, and, in particular, features that had previously been assumed to have defensive functions. While from one perspective it is important that such field evidence is critically re-evaluated, it is also crucial that the pendulum does not swing too far towards this type of viewpoint. Too often in castle scholarship, perhaps, regional study has meant examining individual sites within the confines of a given geographical area (usually a county), and integrated analyses of sites, their interrelationships and hinterlands in other types of unit are urgently needed. Studies of castles within lordships are surprisingly few (see Butler 1992 for a notable exception), and others examining castles within wider structures of medieval lordship fewer still, but highlight one area of clear potential. Another useful illustration of castles in the broader regional framework of history and geography is their mapping and analysis in comparison with various other sorts of settlement phenomenon (e.g. Higham 2000).

An area of study similarly neglected is the status of castles within the context of the sometimes regionally distinctive cultures of medieval Britain (problems of the definition of which were explored in Jope 1963). We might contrast the supposed 'vernacular' and 'regional' qualities of the buildings that populated the manipulated landscapes of castle lords with the higher-status buildings of the castles themselves, which were far less regionally characterised because of the broader cultural horizons of their patrons. While outwardly 'polite' forms of design, castles functioned within the context of very different manorial economies, and this tension - between élite structures and local landscapes - merits further investigation. To what extent, for instance, did the designed environs of a medieval castle represent the superimposed template of an imagined ideal' landscape, as opposed to individualised seigneurial initiative mediated by local circumstances? There is also great potential to illuminate the visual qualities of castle settings in ways less familiar to medieval archaeologists. The concept of the 'viewshed' (the tract of landscape visible with a given location), for instance, has been used to great effect in prehistoric landscape study, but has been avoided almost entirely for documented periods. To what extent could viewshed analysis help us unravel the intentions of those responsible for castle siting, illuminating for instance, the 


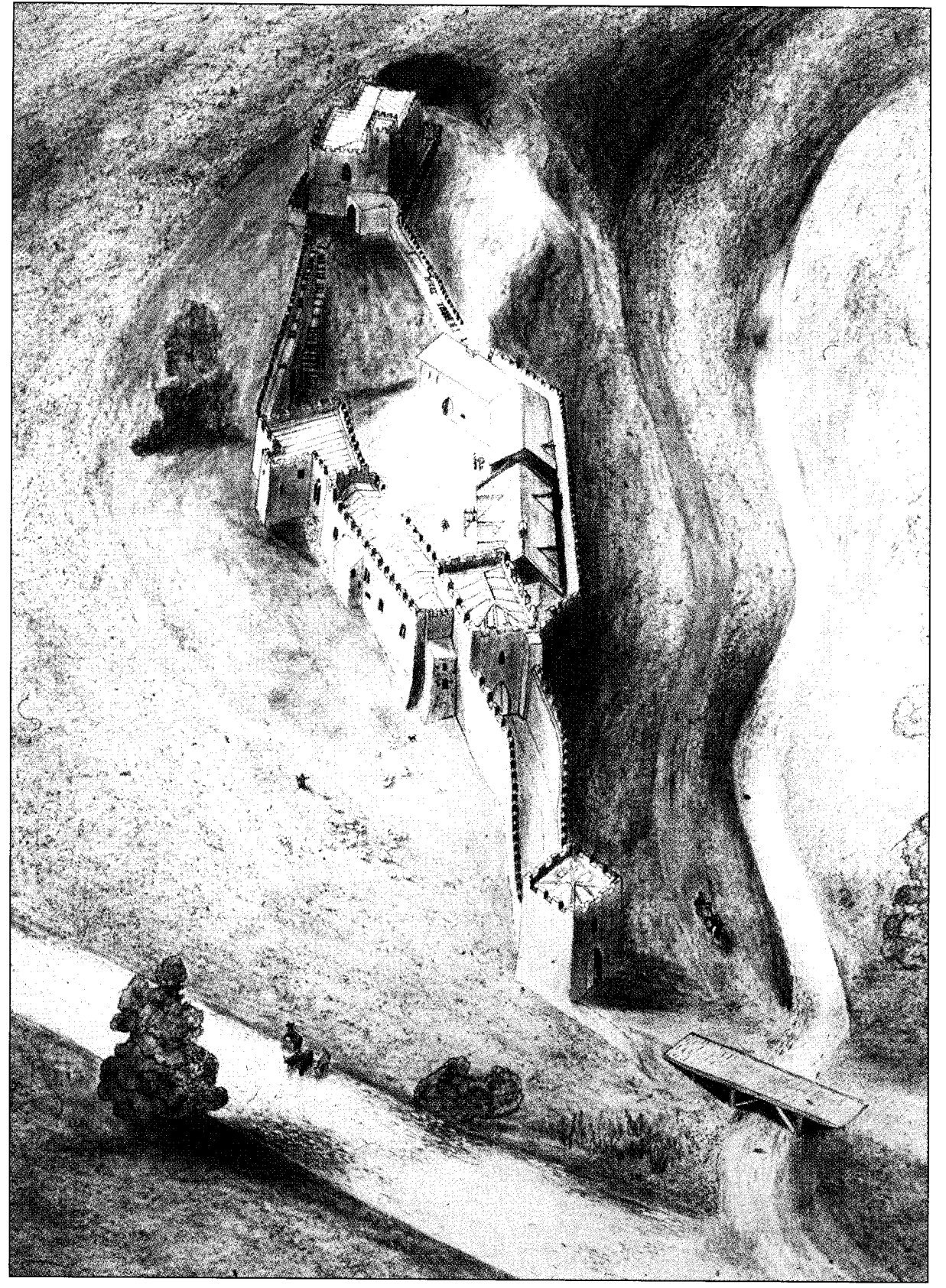

Plate III. Okehampton Devon. Founded by 1086 by the Norman sheriff of Devon, the castle was extensively rebuilt in largely new form in the early fourteenth century. At this time, its landscape contex was enhanced by the development of an adjacent moorland hunting ground into a formal deer park. The new design of the site presented two contrasting images: (right) a 'martial and public face to the north, where it was enclosed by an imposing curtain wall and gatehouse; and (left) a 'domestic' and private face to the south, where domestic ranges on the motte-top and in the bailey were unimpeded by defences. and from which views over the park were provided from comfortable window seats. (Illustration Séan Goddard) intervisibility or otherwise of castles with settlements, deer parks, other lordship sites and, perhaps most importantly, estates and dependent territories?

A category of evidence particularly underexploited is the wealth of literary and art historical source material. While stock sources for instance the alliterative poem Sir Gawain and the Green Knight that reflects fascinating aspects of contemporary perceptions of castles and their settings - have been quoted and requoted, work to date has only scratched the very surface of a data set of massive qualitative potential. Another area of potential is the study of how objection or resistance to the coercive powers of castle lords can be detected, for instance in lord-tenant relationships; yet another is the contrasting patterns of castle building on different types of lordship. Another is the fuller exploitation of the wealth of environmental data from castle sites, and another still the more detailed study of how ecclesiastical sites and religious imagery were reflected and embedded within designed landscapes. These points testify, if nothing else, that future writers on castle studies should not have to provide the customary introductory apology for researching a subject about which all the main questions are sometimes thought to have been asked and answered. Finally, this paper is also something of a plea to those engaged with the study of Britain's historic landscapes not to see castles as somehow lying beyond the remit of landscape history as defined by them, but to engage more fully with their contextual study. 
BIBLIOGRAPHY

Allcroft, A. H., 1908. Eartbwork of England: Prehistoric, Roman, Saxon, Danish, Norman, and Mediaeval (London).

Armitage, E. S., 1904. 'The early Norman castles of England', Engl Hist Rev, 19, pp. 209-45, 417-55.

Armitage, E. S., 1912. The Early Norman Castles of the British Isles (London)

Armitage, E. S., \& Montgomerie, D. H., 1912. 'Ancient earthworks', in The Victoria History of the County of York, Vol. II, ed. W. Page (London)

Aston, M., 2000. Monasteries in the Landscape (Stroud).

Austin, D., 1984. 'The castle and the landscape', Landscape Hist, 6, pp. 69-81.

Barker, P.A., \& Higham, R. A., 1982. Hen Domen Montgomery: a timber castle on the Welsh border (London).

Beeler, J., 1956. 'Castles and strategy in Norman and early Angevin England', Speculum, 31, pp. 581-601.

Beeler, J., 1966. Warfare in England 1066-1189 (Ithaca)

Belloc, H., 1912. Warfare in England (London).

Beresford, G., 1975. The Medieval Clay-Land Village excavations at Goltho and Barton Blount, Soc Medieval Archaeol Monogr No, 6 (London).

Beresford, G., 1987. Goltho: the Development of an early medieval manor c. $850-1150$ (London).

Biddle, M., 1964. "The Excavation of a motte and bailey Castle at Therfield, Herts.', I Br Archaeol Assoc, 27, pp 53-91.

Blair, J., 1981. 'William Fitz Ansculf and the Abinger motte', Archaeol J, 138, pp. 146-8

Braun, H., 1936. The English Castle (London).

Brown, R. A., 1954. Medieval Castles (London)

Butler, L. A. S., 1992. 'The origins of the Honour of Richmond and its castles', Château Gaillard, 16, pp. 6980.

Cameron, A., 1980. 'Laxton before 1635', East Midlands Geogr, 7.6, pp. 219-26

Castle Studies Group, 1987. 'Statement of intent', Castle Stud Group Newsletter 1, p. 2.

Clark, G. T., 1884-85. Mediaeval Military Arcbitecture in England, 2 Vols (London)

Counihan, J., 1990. 'Ella Armitage, Castle Studies Pioneer', Fortress, 6, pp. 51-9.

Crawford, O. G. S., 1953. Archaeology in the Field (London)

Creighton, O. H., 1999. 'Early castles and rural settlement patterns: insights from Yorkshire and the East Midlands', Medieval Settlement Res Group Ann Rep 14, pp. 29-33.

Creighton, O. H., 2000. 'Early castles in the medieval landscape of Wiltshire', Wiltshire Archaeol \& Nat Hist Mag, 93, pp. 105-19

Creighton, O. H., 2002. Castles and Landscapes (London).

Creighton, O. H., 2003. "Castles, lordship and settlement in Norman England and Wales', Hist Today, 53, 4, pp. $12-$ 19

Creighton, O. H., forthcoming. 'Castles and castle-building in town and country', in Town and Country in the Middle Ages, Contrasts, Contacts and Interconnections, ed. C. Dyer \& K. Giles, Soc Medieval Archaeol Monogr.

Creighton, O. H., \& Higham, R. A., 2003. Medieval Castles (Chichester).

Darlington, J., 2001. 'Conclusions', in Stafford Castle: survey, excavation and research $1978-98$. Volume $I-$ The Surveys, ed. J. Darlington (Stafford), pp. 147-52.

Dixon, P., 1998. 'Design in castle-building: the controlling of access to the lord', Chateau Gaillard, 8, pp. 47-57.

Eales, R., 1990. 'Royal power and castles in Norman England', Medieval Knightbood, 3, pp. 49-78.

Everson, P., Taylor, C. C., \& Dunn, C. J., 1991. Change and Continuity: nural settlement in north-west Lincolnshire (London).

Everson, P., 1988. 'What's in a name? 'Goltho', Goltho and Bullington', Lincolnshire Hist \& Archaeol, 23, pp. 93-9.

Everson, P., 1990. 'The problem of Goltho', Medieval Settlement kes Group Rep 5, pp. 9-14
Everson, P., Brown, G., \& Stocker, D), 2000. 'The castle earthworks and landscape context', in Ludgershall Castle, Wiltshire: a report on the excavations by Peter Addyman, 1964-1972, ed. P. Ellis, Wiltshire Archaeol \& Nat Hist Soc Monogr No. 2 (Devizes), pp. 97-119.

Grose, F., 1801. Military Antiquities Respecting a History of the English Army from the Conquest to the Present Day (London).

Hamilton Thompson, A., 1912. Military Architecture in England During the Middle Ages (London).

Harvey, A., 1911. The Castles and Walled Towns of England (London).

Herring, P., 2003. 'Cornish medieval deer parks', in The Lie of the Land. Aspects of the bistory and archaeology of the designed landscape in the south west of England, ed. R. Wilson-North (Exeter), pp. 34-50.

Heslop, T. A., 1991. Orford Castle: nostalgia and sophisticated living', Archit Hist, 34, pp. 36-58.

Higham, R. A., 1977. 'Excavations at Okehampton castle, Devon. Part I: the motte and keep', Proc Devon Archaeol Soc, 35, pp. 1-43.

Higham, R. A., 1982. 'Early castles in Devon, 1068-1201', Château Gaillard 9-10, pp. 102-15.

Higham, R. A., 2000. 'Castles, fortified houses and fortified towns in the Middle Ages', in Historic Atlas of the SouthWest, ed. R. Kain \& W. Ravenhill (Exeter), pp. 136-43.

Higham, R. A., 2001. 'Okehampton Castle, Devon: interpretation, conservation, presentation and restoration from circa 1895 to circa 1995, Europa Nostra Fédération Pan-Européenne du Patrimoine, Bull 55, pp. 129-52.

Higham, R. A., \& Barker, P. 1992. Timber Castles (London)

Higham, R. A., \& Barker, P., 2000. Hen Domen, Montgomery. A timber castle on the English-Welsh horder: a final report (Exeter)

Higham, R. A., \& Saunders, A., 1997. 'Public and private defence in British medieval towns', Europa Nostra Fédération Pan-Européenne du Patrimoine, Bull 50, pp. $117-28$.

Hill, C., \& Klemperer, W., 1995. 'The deserted medieval settlement at Stafford Castle', Medieval Village Res Group Ann Rep 33, pp. 19-22.

Hill, P., \& Wileman, J., 2002. Landscapes of War: the archaeology of aggression and defence (Stroud)

Hope Taylor, B., 1950. "The excavation of a motte at Abinger in Surrey', Archaeol J, 107, pp. 15-43.

Hoskins, W. G., 1955. The Making of the English Landscape (London).

Jecock, M., \& Corbett, G., 2001. 'The earthwork and architectural survey', in Stafford Castle, ed. Darlington, pp. 83-115.

Johnson, M., 2002. Behind the Castle Gate: medieval to Renaissance (London).

Jope, E. M., 1963. 'The regional cultures of medieval Britain', in Culture and Environment, Essays in Honour of Sir Cyril Fox, ed. I. L. L. Foster \& L. Alcock (London), pp. 327-50.

King, D. J. C., 1983. Castellarium Anglicanum, 2 Vols (London).

King, D. J. C., \& Spurgeon, J. 1965. Mottes in the Vale of Montgomery', Archaeologica Cambrensis, 114, pp. 69-5.

Le Patourel, H. E. J., 1976. The Norman Empire (Oxford).

Liddiard, R., 2000a. 'Castle Rising, Norfolk: a "landscape or lordship?" , Anglo-Norman Stud, 22, pp. 169-86.

Liddiard, R., 2000b. "Landscapes of Lordship": Norman castles and the countryside in medieval Norfolk. 1066-1200, Br Archaeol Rep, Br ser 309 (Oxford).

Liddiard, R., ed., 2003. 'Introduction', in Anglo-Norman Castles, ed. R. Liddiard (Woodbridge), pp. 1-21.

Liddiard, R., forthcoming. Castles in Context (Macclesfield).

Mayes, P., \& Butler, L., 1983. Sandal Castle Excavations 1964 1973: a detailed archaeological report (Wakefield).

McNeill, T. E., \& Pringle, M., 1997. 'A map of mottes in the British Isles', Medieval Archaeol, 41, pp. 220-2.

Morris, R. K., 1989. Churches in the Landscape (London). 
Muir, R., 2000. The New Reading the Landscape, Fieldwork in Landscape History (Exeter)

Munby, J., 1985. 'Portchester and its region', in Excavation at Portchester Castle: Vol. IV, Medieval, the Inner Bailey, ed. B. Cunliffe \& J. Munby, Rep Res Comm Soc Antiq London No. 43 (London), pp. 270-95.

O'Conor, K. 1)., 1998. The Archaeology of Medieval Rural Settlement in Ireland (Dublin)

Oman, C., 1898. The Art of War in the Middle Ages, 2 Vols (London).

Poole, A. L., 1955. From Domesday Book to Magna Carta (Oxford).

Rahtz, S., \& Rowley, T., 1984. Middleton Stoney: excavation and survey in a north Oxfordshire parish 1970-1982 (Oxford).

RCHME 1981. An Inventory of the Historical Monuments in the County of Northampton, Vol. III: Archaeological Sites in North-West Northampton (London).

Rowley, T. 1978. Villages in the Landscape (London)
Saunders, A. D., 1993. 'The English medieval castle as country house', Europa Nostra Fédération PanEuropéenne du Patrimoine Bulletin, 49, pp. 49-54.

Stocker, D., 1992. 'The shadow of the general's armchair' Archaeol J, 149, pp. 415-20.

Taylor, C. C., 1983. Village and Farmstead: a bistory of nural settlement in England (London).

Taylor, C. C., 1998. Parks and Gardens of Britain (Edinburgh).

Taylor, C. C., 2000. 'Medieval ornamental landscapes', Landscapes 1,1 , pp. 38-55.

Thompson, M. W., 1994. The military interpretation of castles', Archaeol J, 151, pp. 439-45.

Welfare, H., Bowden, M., \& Blood, K., 1999. 'Fieldwork and the castles of the Anglo-Scottish Borders', in Patterns of the Past: essays in landscape archaeology for Christopher Taylor, ed. P. Pattison, D. Field \& S. Ainsworth, Oxford), pp. 53-60. 